\title{
A CHECK ON THE ANATOMICAL ACCURACY OF INTRA-ARTICULAR HIP INJECTIONS IN RELATION TO THE THERAPY OF COXARTHRITIS
}

\author{
BY \\ MARJORIE M. DOBSON
}

In various countries for many years, orthopaedic surgeons have given intra-articular injections into the hip-joint, for the better study of the anatomy of the joint; especially in relation to congenital dislocations of the hip.

\section{Review of the Literature}

Cornet (1933) insufflated this joint in infants with air and oxygen, and reported on 14 cases of subluxation of the hip-joint in which radiographs taken after the injection showed a very clear definition of the articulation and its capsule.

Various radio-opaque solutions have been used, of which mention may be made of "thorotrast", " abrodyl", " uro-selectan B", "diagnerol", and " tenebryl".

In France, Leveuf and Bertrand (1937) found that most radio-opaque solutions gave satisfactory results in patients chosen from cases of subluxation of the hip-joint. The joint was injected from the lateral aspect, from a point just above the great trochanter of the femur.

Gunnar Wiberg (1939) used a specially prepared solution of perbrodil in making arthographs from twenty-two normal or nearly normal hip-joints from cases which presented for operation for some other reason. The joint was approached from the anterior, and the needle inserted just below Poupart's ligament, $1 \mathrm{~cm}$. outside the femoral artery. After the head of the femur had been reached by the needle, the point was withdrawn a few $\mathrm{mm}$. before the injection was made.

Thus, most studies in arthography have been made from the orthopaedic point of view, and preceding operative procedures.

Other investigators have injected the hip-joint for therapeutic reasons. Thus Grant Waugh (1938), having studied the physio-chemical changes occurring in normal synovial fluid after trauma, especially the changes in the hydrogen ion concentration, treated minor joints after injury with intra-articular lactic acid injections. His results were beneficial in a high percentage of cases. Later (1945) Waugh reported on twenty-five cases of coxarthritis so treated. Recovery of function and relief of pain occurred in between 50 and 60 per cent. of these.

Warren Crowe (1944) showed the benefit from treatment by intra-articular injections of an acid potassium phosphate solution, in two-thirds of his cases of coxarthritis. He used the anterior approach in most of his cases.

In France Coste and Morin (1939) had been trying various analgesic solutions intra-articularly for the treatment of coxarthritis. They came to the conclusion that there was a purely functional relief of the condition.

In America, Tarsy (1938) used 1 per cent. procaine into the hip-joint in the same disease.

It will be noticed from the literature that many observers used combined peri-arthritic and intraarthritic injections in the treatment of osteoarthritis of the hip-joint. Some used only small amounts of injection fluid, although Grant Waugh and Warren Crowe advise an amount of $20 \mathrm{c.cm}$. for this joint. Almost all have owned to a few failures in introducing the fluid in its entirety into the synovial cavity. The beneficial effects of these intra-articular injections in the treatment of coxarthritis have been attributed by these investigators either to the chemical composition, or to the $\mathrm{pH}$ of the solution injected, or to the analgesic solution breaking the reflex of painful spasm.

\section{Discussion}

In my opinion the most important part of the injection treatment of coxarthritis is that the whole capacity of the joint should be taken up by the appropriate solution injected, although this latter must of course have the correct physio-chemical composition and isotonicity. (Analgesic solutions will not be discussed here.)

An amount of fluid equal to the capacity of the joint will exert a centrifugal, equalizing, hydrostatic pressure on the whole synovial membrane and its villi, albeit short-lived owing to absorption.

It is possible that in the earlier stages of osteoarthritis of the hip, and especially in the "rheumatoid" type that also occurs, this sudden equalizing 
TABLE 1

RESULTS OF INJECTING THIRTY-THREE JOINTS WITH CARMINE IN GLYCERINE

\begin{tabular}{|c|c|c|c|c|c|c|c|c|c|}
\hline \multirow[b]{2}{*}{ Age } & \multirow{2}{*}{\multicolumn{3}{|c|}{ Disease }} & \multicolumn{2}{|c|}{ Successful } & \multicolumn{2}{|c|}{ Unsuccessful } & \multirow[b]{2}{*}{ Not seen } & \multirow[b]{2}{*}{ Case } \\
\hline & & & & Jelly & Staining & $\begin{array}{c}\text { Ilio-femoral } \\
\text { ligament }\end{array}$ & Muscle & & \\
\hline $\begin{array}{l}74 \\
74 \\
80 \\
80 \\
74 \\
73 \\
73 \\
74 \\
73 \\
73 \\
91 \\
71 \\
84 \\
84 \\
73 \\
73 \\
76 \\
76 \\
85 \\
85 \\
81 \\
71 \\
64 \\
64 \\
68 \\
71 \\
80 \\
80 \\
64 \\
86 \\
69 \\
76 \\
76\end{array}$ & $\begin{array}{l}\text { Cardiovascular degener } \\
\text { Cardiovascular degene } \\
\text { Cerebral thrombosis } \\
\text { Cerebral thrombosis } \\
\text { Cardiovascular degener } \\
\text { Cancer of rectum } \\
\text { Cystitis .. } \\
\text { Cardiovascular degener } \\
\text { Cancer of rectum } \\
\text { Cancer of rectum } \\
\text { Senile } \ldots \\
\text { Bronchitis and emphys } \\
\text { Senile .. . . } \\
\text { Senile } \ldots \\
\text { Myocardial degeneratio } \\
\text { Myocardial degeneratic } \\
\text { Cancer of pharynx } \\
\text { Cancer of pharynx } \\
\text { Bronchial pneumonia } \\
\text { Bronchial pneumonia } \\
\text { Uraemia .. } . . \\
\text { Uraemia .. } . . \\
\text { Bronchial pneumonia } \\
\text { Bronchial pneumonia } \\
\text { Arterial sclerosis } \\
\text { Uraemia ... } \\
\text { Cancer of colon } \\
\text { Cancer of colon } \\
\text { Cardiovascular degener } \\
\text { Bronchial pneumonia } \\
\text { Advanced paralyses } \\
\text { Paget's disease ... } \\
\text { Paget's disease ... }\end{array}$ & 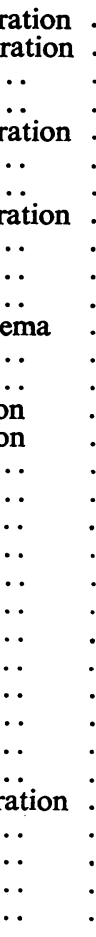 & 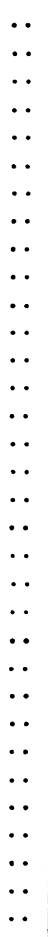 & $\begin{array}{l}\bar{Z} \\
\bar{Z} \\
\text { yes } \\
\overline{-} \\
\text { yes } \\
\text { yes } \\
\text { yes } \\
\overline{-} \\
\text { yes } \\
\text { yes } \\
\text { yes } \\
\text { yes } \\
\text { yes } \\
\bar{Z} \\
\bar{Z} \\
\bar{Z} \\
\text { yes } \\
\bar{Z} \\
\bar{Z} \\
\overline{\text { yes }} \\
\text { yes }\end{array}$ & $\begin{array}{l}\text { yes } \\
= \\
= \\
= \\
= \\
= \\
= \\
= \\
= \\
= \\
= \\
= \\
\text { yes } \\
\text { yes } \\
\text { yes } \\
\text { yes } \\
\text { yes } \\
\text { yes } \\
\text { yes } \\
\text { yes } \\
\overline{-} \\
\overline{-}\end{array}$ & 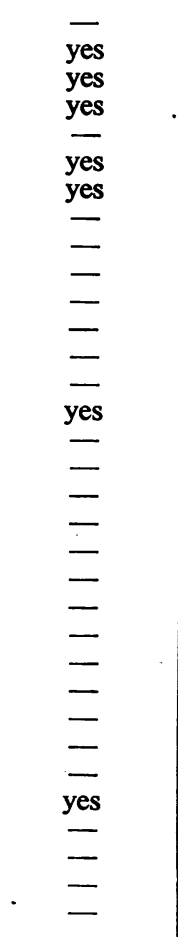 & $\begin{array}{l}\bar{z} \\
\bar{z} \\
\bar{z} \\
\bar{z} \\
\bar{z} \\
\overline{\text { yes }} \\
\bar{z} \\
\bar{z} \\
\bar{z} \\
\bar{z} \\
\bar{z} \\
\bar{z} \\
\bar{z} \\
\bar{z} \\
\bar{z} \\
\bar{z} \\
\bar{z} \\
\bar{z} \\
\bar{z}\end{array}$ & 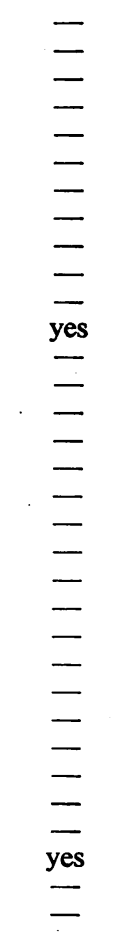 & $\begin{array}{r}1 \\
2 \\
3 \\
4 \\
5 \\
6 \\
7 \\
8 \\
9 \\
10 \\
11 \\
12 \\
13 \\
14 \\
15 \\
16 \\
17 \\
18 \\
19 \\
20 \\
21 \\
22 \\
23 \\
24 \\
25 \\
26 \\
27 \\
28 \\
29 \\
30 \\
31 \\
32 \\
33\end{array}$ \\
\hline & Totals $\quad .$. & .. & $\ldots$ & 12 & 9 & 7 & 3 & 2 & 33 \\
\hline & & & & \multicolumn{2}{|c|}{$\underbrace{}_{21}$} & \multicolumn{2}{|c|}{10} & 2 & 33 \\
\hline
\end{tabular}

and expanding pressure of isotonic solution will separate congested villi, and in any type of coxarthritis will facilitate drainage through the villi. In the more chronic cases there may be some stretching of the capsule and temporary separation of eroded cartilages, except in the very advanced cases.

Thus, apart from the physio-chemical action of the fluid introduced, there occurs a threefold effect if sufficient fluid is used. First, there is a gradual replacement of the existing synovial fluid, or a "washing" out" through villous absorption; secondly there is an "ironing out" of the synovial membrane ; and lastly there may in some cases be a stretching of the capsule.

Over a period of four years, in my own cases of coxarthritis treated by the acid phosphate solution, I have noticed how often an advanced osteo- arthritis, with much contraction of capsule and joint destruction, will "take" only perhaps 10 or $15 \mathrm{c.cm}$. of solution at the first injections, before back-pressure occurs in the syringe, whereas later the amount retained intra-capsularly may be considerably increased. It is because I feel that the most important factor in treatment of coxarthritis by intra-articular joint injection is that all the fluid should enter the joint to the full capacity of the joint and that there should be no peri-articular leakage, that I made the following control injections on the cadaver. It may be owned that the results may reflect on the skill of the individual injector of solution ; but this will only serve to emphasize the importance of a skilled and experienced technique in this treatment in the living, of coxarthritis by " acid" therapy. 


\section{Results in the Cadaver}

The approach was from the anterior, in these cases, taking a point 1 inch outside the femoral artery, on a line joining the superior border of the trochanter to the pubic ridge.

My first results proved to be of little value, because the contraction of the tissues by the preservative used on the cadaver diminished the size of the joint cavity and made difficult the differentiation of the various layers of muscle, ligament, and capsular structures, by the puncture needle. This was partly overcome by injecting the cadaver within 24 to 48 hours after its arrival from the mortuary.

The question of a suitable dye was the next difficulty, as an aqueous solution was soon absorbed from the joint and dissipated into the surrounding tissues, before the time of dissection of the limb by the students. At length a suitable solution of carmine in glycerine was tried, which, injected hot, was found at the subsequent dissection at the site of injection in the form of a jelly.

Accuracy of the injection was made more difficult in the cadaver by several factors ; namely, the additional surface marking necessary for the femoral artery, whose palpation is so useful in the living; and the severe deformities and senility of the greater number of subjects. I also missed the help given by the living patient as to sensitivity of the needle puncture, and changes in sensation during the operation.

TABLE 2

SUMMARY OF RESULTS

\begin{tabular}{lllll|r}
\hline Number of Cases &.. & $\ldots$ & $\ldots$ &.. & 33 \\
\hline Successful $\ldots$ & $\ldots$ & $\ldots$ & $\ldots$ & $\ldots$ & 21 \\
Unsuccessful & $\ldots$ & $\ldots$ & $\ldots$ & $\ldots$ & 10 \\
No result (absorption of dye) & $\ldots$ & $\ldots$ & 2 \\
Percentage of successful results & $\ldots$ & $\ldots$ & 64 \\
\hline
\end{tabular}

\section{Results}

The results are given in the form of Tables. The number of joints injected was thirty-three. Results were considered to be completely successful if the mass of jelly was inside the acetabular cavity of the joint; and moderately successful if there was a red dye staining over the acetabulum cavity, or over the head of the femur. Unsuccessful results were those in which the dye-jelly was in the iliofemoral ligament, or in the muscles surrounding the capsule (usually the ilio-psoas tendon).

These results may appear to be somewhat disappointing; they show a successful result in 65 per cent. of cases only ; but in view of the fact that in the living patient periodic injections are made, of which many at least will be completely intra-capsular, and bearing in mind the above-mentioned difficulties of technique, they are less discouraging than might at first appear. They may possibly explain why, instead of 100 per cent. successful results in intraarticular therapy, there are only perhaps 65 per cent.

\section{Summary}

Results are given of a few consecutive intraarticular hip injections in the cadaver, preceded by a short survey of previous work done in intraarticular injections of the hip-joint.

The method was the anterior approach in these cases ; but at present I am making a comparative study of results using the lateral approach.

Thanks are due to Professor Lucas Keene and the Council of the London School of Medicine for permission and facilities to carry out this investigation; also to the laboratory technician and the curator of the Anatomy Department for their assistance in producing suitable material and subjects for injection.

Since writing this article, Bayer and Chayer have reported on 29 cases of hip-injection treatment in osteo-arthritis. The opinion they give as to the benefit of this therapy is partly that discussed above. Messrs. Allen and Hanbury, Ltd., are kindly endeavouring to prepare a more viscous solution of acid phosphate, and, since December, 1947, have been undertaking research on these lines for me.

\section{REFERENCES}

Baker, D. M., and Charden, M. S. (1948). Lancet, 1, 93. Cornet, J. (1933). Scalpel Brux., 86, 1482.

Coste, F., and Morin, M. (1939). Soc. Méd. Hôp. Paris, $55,1009$.

Crowe, H. Warren (1944). Lancet, 1, 563.

Leveuf, J., and Bertrand, P. (1937). Presse Méd., 45, 437.

Tarsy, J. M. (1938). Med. Rec., 148, 269.

Waugh, W. Grant (1936). Lancet, 2, 976.

- (1938). Ibid., 1, 487.

(1945). Brit. med. J., 1, 873.

Wiberg, Gunnar (1939). Acta Chirurg. Scand., 83, supp. 58.

\section{Vérification de la Précision Anatomique des Injections Intra-articulaires de la Hanche en Relation avec le Traitement de l'Arthrite de la Hanche \\ RÉSUMÉ}

Cet article donne les résultats de trente-trois injections consécutives dans l'articulation de la hanche sur le cadavre, ainsi qu'une brève revue des travaux antérieurs portant sur les injections dans l'articulation de la hanche. Les résultats ont été considérés comme excellents lorsque la masse de gelée se trouvait dans la cavité acétabulaire de l'articulation; et comme assez bons lorsque l'on constatait une coloration rouge au-dessus de la cavité acétabulaire ou au-dessus de la tête du fémur. Les mauvais résultats étaient ceux dans lesquels la gelée colorée se trouvait dans le ligament ilio-fémoral, ou dans les muscles entourant la capsule (généralement le tendon du psoas). La voie d'accès choisie était la voie antérieure, mais l'auteur procède actuellement à une étude comparative des résultats obtenus par la voie d'accès latérąle.

Les résultats n'ont été excellents que dans 65 pour cent des cas ; mais si l'on considère le fait que sur le malade vivant on procède à des injections périodiques, et si l'on tient compte de la difficulté de la techniquẹ, cette proportion est moins décourageante qu'elle ne semble a priori. 